\title{
SUBJECTIVITY AND OBJECTIVITY IN THEOLOGICAL HERMENEUTICS: THE POTENTIAL OF LOVE FOR INTERFAITH ENCOUNTER
}

\author{
Werner G. Jeanrond*
}

\begin{abstract}
This article investigates the nature and significance of hermeneutics in theological thinking. Two principal approaches to hermeneutics in theology, i.e. a hermeneutics of revelation and a hermeneutics of signification, are examined and their respective implications for theological thinking are discussed within a Christian horizon. However, it is argued that all religious traditions need to come to terms with their respective linguistic and hermeneutical condition and with the plurality of interpretations arising from the necessary interplay between subject and object in every act of interpretation. A concept of love as critical human praxis is proposed as the most appropriate way of dealing with differences of understanding sacred texts, traditions and human experiences in this universe, culminating in the call for a hermeneutics of love in theology.
\end{abstract}

Key Words: Hermeneutics, theology, plurality, love, truth, subjectivity, objectivity, Gadamer, Schleiermacher, Ricour

\section{Preface}

Islam gratefully acknowledges the Qur'ān as divine revelation given to the Prophet Muhammad, a revelation that makes use of language and its communicative potential. Hence, Qur'anic studies need to reflect on the nature and communicative potential of language in order to approach this divine revelation most adequately and responsibly. Hermeneutical thinking, therefore, is essential also to Qur'anic studies. Moreover, the reflections on hermeneutics in the religious traditions committed to divine revelation through language might

University of Oxford, Oxford-UK. Email: werner.jeanrond@theology.ox.ac.uk

(C) 2013 Al-Bayān Journal.

Published by Department of al-Qur'an and al-Hadith, Academy of Islamic Studies,

University of Malaya, 50603 Kuala Lumpur - Malaysia. 
benefit from learning from each other. The following contribution is offered in this spirit of gratitude, humility and mutual enrichment.

Already the admission that in certain situations we human beings need hermeneutics points to the fact that understanding is not always the self-evident outcome of human interaction. Understanding does not always happen automatically. Rather human communication occurs on different levels of complexity: While writing an instruction of how to use an appliance or even a life jacket intends to reduce communicative complexity as far as possible, composing a poem requires a higher level of communicative complexity in order to generate a certain density of expression, and understanding a poem calls for a corresponding ability in the reader. Depending on intentions and circumstances, our communicative efforts make use of different levels of density and of particular conventions which together promise to steer the reception of what is to be communicated.

When interpreting any aspect of reality, including written texts, it is the understanding person, the subject, that invests his or her subjectivity into the communicative process and in this way initiates the hermeneutical process. How much subjectivity is needed in a specific hermeneutical situation in order to strive for and, in the best scenario, reach a certain measure of objectivity in the act of communication?

At the outset, I wish to examine the nature and scope of theological understanding in some detail. What sort of linguistic processes condition theological hermeneutics and which measure of subjectivity is called for in these processes? Second, I shall investigate the significance of an inner-ecclesial pluralism for an appropriate hermeneutics of faith. Third, I shall conclude with some remarks on a hermeneutics of love. Obviously, as a Christian theologian I am using examples and illustrations from my own religious tradition. However, my reflections on hermeneutics might also be of relevance to Islam and other religious traditions concerned with the interpretation both of sacred Scripture and of the universe at large. 


\section{The Significance of Hermeneutics for Theology}

It would be misleading to speak simply of the theological hermeneutics. Rather the point is to establish which hermeneutics may be needed in theology. Discussing different theological methods might help us to appreciate the significance given to hermeneutics in particular theologies. The crucial question is: does theology call either for a special theological hermeneutics or for a general philosophical hermeneutics?

In more recent Christian thinking, the Swiss theologian Karl Barth (1886-1968) and his many followers have been eager to subordinate hermeneutical considerations to a well-defined understanding of divine revelation in Scripture. They have claimed to know what revelation is even before beginning the actual process of communication with biblical texts, even though it is this very process which first of all enables understanding of revelation through the acts of interpreting biblical texts. In other words, in this process of understanding human subjectivity has been subordinated to an assumed objective grasp of revelation. Here, a hermeneutics of revelation can be identified which attempts to undercut the essential linguisticality of theological communication. Accordingly, in the beginning is no longer any logos, language or word, but a reference to revelation which is independent of any linguistic process and which always already has predetermined any understanding of the words in the texts of sacred Scripture.

Unlike Barth and the Barthians, Friedrich Schleiermacher, Rudolf Bultmann, Hans-Georg Gadamer, Paul Ricœur, Claude Geffré, David Tracy, Edward Schillebeeckx and other theologians and philosophers in the Western tradition have defended the insight into the essential linguisticality of all human understanding. In the philosopher Hans-Georg Gadamer's words, "Being that can be understood is language". ${ }^{1}$ The resulting hermeneutics may be called a 'hermeneutics of signification'. In this hermeneutics the linguistic signs and symbols first of all mediate an access to the meaning of texts - oral and written. Humans communicate through linguistic forms, i.e. through texts, and there is no text-free access to any sort

Hans-Georg Gadamer, Truth and Method, trans. rev. Joel Weinsheimer and Donald G Marshall (London: Sheed \& Ward, 1989), 474. 
of revelatory knowledge. Rather humans must reflect on how this communication through texts happens in detail. ${ }^{2}$ Which are its possibilities, limitations and specific problems?

Hence theology must choose: does it wish to engage in a hermeneutics obedient to its own assumed theological premises, i.e. a theological hermeneutics? Or does it wish to participate in a larger philosophical search for appropriate hermeneutical insights in co-operation with all other disciplines thus concerned - and to become a discipline that is fully conscious of its own hermeneutical foundation and constitution?

Answering this question of the relationship between theology and hermeneutics confronts us immediately also with the anthropological presuppositions of theological thinking. Whereas a theological hermeneutics basically mistrusts human communication and wishes to refer directly to divine communication, somehow bypassing human communication, a theology facing up to its hermeneutical condition will be interested in divine communication as it happens through human beings. Both types of theology affirm transcendence, yet they conceptualise it in different ways, and that has wide-ranging consequences for theological thinking.

Of course, in spite of Karl Barth's in my eyes uncritical theological hermeneutics I still take his protest against any purely historicalcritical exegesis seriously, i.e. against a form of interpretation that is exclusively concerned with historical facts and causes emanating from biblical texts and that thus neglects the theological potential of these texts. I also share Barth's challenge to the historical-critical exegetes to become more critical in their thinking. ${ }^{3}$

However, the alternative between a theological hermeneutics interested in disclosing and a priori securing the theological dimensions of biblical texts, on the one hand, and a philosophical hermeneutics which a priori rejects any disclosure of theological dimensions in a text as unscientific, seems to me to be false. That

See, for example, Werner G. Jeanrond, Text and Interpretation as Categories of Theological Thinking, trans. Thomas J. Wilson (Eugene, Oregon: Wipf and Stock, 2005), and Theological Hermeneutics: Development and Significance (London/New York: SCM, 1994).

3 Cf. Jeanrond, Theological Hermeneutics, 127-137. 
is why I wish to argue in favour of a critical hermeneutics that is prepared to take seriously the theological potential of texts without subordinating its critical faculties to this very process. I understand hermeneutics as a critical and self-critical art of text-interpretation.

This artistic dimension of hermeneutics has been emphasised again and again in hermeneutical discussions since the Enlightenment, because hermeneutics is always more than mere method, precisely because it necessarily involves a subjective moment. Moreover, hermeneutics can never be reduced to a merely universally valid technique. Gadamer (1900-2002) has been one of the most influential campaigners against any attempt to reduce hermeneutics to a universally applicable method. He was concerned with disclosing and understanding the hermeneutical nature of philosophical thinking.

The hermeneutics that I characterise as philosophic is not introduced as a new procedure of interpretation or explication. Basically it only describes what always happens whenever an interpretation is convincing and successful.... For, understanding is more than the adroit application of a skill. It always harvests a broadened and deepened self-understanding. But that means hermeneutics is philosophy, and as philosophy it is practical philosophy. ${ }^{4}$

Interestingly enough, Gadamer demonstrated these philosophical insights with the help of examples from text-interpretation. That is why his hermeneutical programme could more easily be identified (or misunderstood) as a method of interpretation. He defended himself as follows:

As an old philologist I may be forgiven for having exemplified all of that with the help of 'being-inrelation-to-the-text'. In truth the hermeneutical experience is totally enmeshed in the general nature of human praxis which includes essentially, though

Hans-Georg Gadamer, Reason in the Age of Science, trans. Frederick G. Lawrence (Cambridge, Mass./London: MIT Press, 1981), 111-112. 
in secondary fashion, the understanding of what is written. Hermeneutical experience extends as far as the intellectual beings' willingness to engage in conversation may conceivably reach. ${ }^{5}$

In spite of Gadamer's brave effort, the tension between a general hermeneutical reflexion, on the one hand, and a hermeneutical methodology for particular disciplines concerned with understanding, such as theology, jurisprudence, literary criticism, psychology, art history, musicology etc., on the other hand, cannot be fully ignored because our general hermeneutical insights are always gained in the actual struggle with concrete hermeneutical challenges. Therefore, a critique of Gadamer's anti-methodological attitude, such as the one presented by Paul Ricœur (1913-2005), is indeed necessary. However, this critique should not overlook that Gadamer's protest against any sort of objectification of hermeneutics also raises a valid concern. It was Gadamer's work, whose chief concern was to shed light on the hermeneutical constitution of human existence, which had stressed the staunch and dynamic relationship between self-understanding and text-understanding. Understanding must always be thought of in terms of a fusion of two horizons, in our case the horizon of the understanding subject and the horizon of the text calling to be understood. Gadamer tried to grasp the dynamics of understanding with the help of the concept of the game (Spiel) in order to highlight the fact that the process of understanding is always kept going by different subjects involved in the process of communication and that their interaction can never be fully programmed or anticipated in advance. ${ }^{6}$ Friedrich Schleiermacher (1768-1834) had already concluded that "approximation" (Annäherung) was the only realistic goal of any hermeneutical effort. ${ }^{7}$ The total understanding of complex texts is never a realistic aim.

Schleiermacher named the two poles of text-understanding "grammatical interpretation" and "psychological/technical interpretation". For him "grammatical interpretation" referred to the

Hans-Georg Gadamer, "Replik", in Hermeneutik und Ideologiekritik (Frankfurt am Main: Suhrkamp, 1980), 283-317, here 314 (my translation).

Cf. Gadamer, Truth and Method, 101-134.

Cf. Jeanrond, Theological Hermeneutics, 46-47. 
linguistic or material aspect of linguistically mediated understanding. And the (for us post-Freudians today so strange) expression "psychological interpretation" was to refer to the necessary subjective aspect of understanding. At times Schleiermacher also talked about divination or the divinatory aspect of understanding. This concept was to point to the necessarily personal and artistic aspect of any understanding. ${ }^{8}$

In spite of all difference in detail, Schleiermacher and Gadamer are agreed upon that understanding needs the subject and must never be reduced to an automated process. Understanding is not a knowledge produced by engineers, but the work of engaged human persons. Both Schleiermacher and Gadamer gained their hermeneutical insights from the praxis of interpreting literary, philosophical, and theological texts, which means texts composed with a certain communicative density.

The French philosopher Paul Ricœur went a significant step further than his famous German predecessors on whose work he had built his own hermeneutical thinking. In much greater detail than Schleiermacher or Gadamer, Ricour dealt with the textuality of texts, that is with the more precise identification of the genres through which we communicate in literary or theological contexts. He distinguished between predominantly narrative, doxological, legal, and prophetic text-genres which in turn call for respective strategies of reception. ${ }^{9}$

Ricœur underlined the autonomy of the text, i.e. the fact that knowledge of the author may not be necessary at all for understanding a text. Hence, Ricour shifted the interpretative attention to those dimensions which characterise a text as a work, a work that calls for understanding more than for identifying the author's intention or the original conditions in which the text came into being. Understanding the text as a work rehabilitates the text as text and guards it from the dissolution into its constitutive parts, i.e. sentences or words. A text is always more than the sum of its parts. Of course, the parts forming a text may well be distinguished,

See ibid., 44-50.

Paul Ricœur, The Conflict of Interpretations: Essays in Hermeneutics, ed. Don Ihde (Evanston: Northwestern University Press, 1974), 482. 
explained and assessed, but the whole of the text always calls for more than such detailed attention. It demands interpretation and as such a holistic approach on the part of the interpreting subject. The interpretation of complex texts needs such a holistic approach to the textuality of the text. ${ }^{10}$

Obviously, communicative competence and linguistic attention are very important for text-interpretation; but they cannot replace the necessarily subjective moment of any interpretative act. It is the human subject that offers the overall projection of the text's whole. Thus, Ricœur overcame Gadamer's anti-methodological attitude and further sharpened the art of interpretation by widening its horizon now to include linguistic connectivity. However, together with Gadamer and Schleiermacher he stressed the significance of interpretation for the interpreting subject her- or himself. "Every hermeneutics is thus, explicitly or implicitly, self-understanding by means of understanding others." 11

Every act of text-interpretation requires not only an attentive understanding, but also a competent, critical and self-critical explanation on its way toward a deeper appreciation of the text as text. Again and again Ricœur attempted to describe the dynamics and principal openness of the act of interpretation. At first he distinguished between different levels of naïveté in order to emphasise the fact that we as interpreters cannot escape from our naïveté, that means from our necessarily limited perspective of understanding. Similarly, Gadamer had spoken about the constructive role of our prejudices or pre-understandings when we interpret texts. These pre-understandings need to be addressed and worked through, but we can never fully overcome them. In his later publications, Ricœur spoke of three levels of mimesis: prefiguration, configuration, and refiguration. These levels of mimesis call for respective attitudes in interpretation. ${ }^{12}$ The critique of ideologies must always be a part of these considerations. Here, Ricœur was in agreement with the philosopher Jürgen Habermas. ${ }^{13}$

\footnotetext{
10 Cf. Jeanrond, Theological Hermeneutics, 70-77.

11 Ricœur, The Conflict of Interpretations, 17.

12 Paul Ricœur, Time and Narrative, 3 vols. (Chicago: University of Chicago Press, 1984$88)$.

13 See Jeanrond, Theological Hermeneutics, 67-68.
} 
In my own work I have attempted to take these reflexions further in order to grasp more fully the objective and subjective aspects of textual communication and their co-operation in the act of interpretation. For this present investigation two thoughts might be of particular interest:

A first thought concerns the recognition of the dialectics of textproduction and text-reception. Every text is composed in a specific genre which in turn can also be recognised and understood as such by its recipients. Moreover, every text is composed in a particular personal style. Genre and style of a text fuse communicative conventions and personal aspects to a new whole in the process of communication. ${ }^{14}$

Sometimes one recognizes offences against those generic conventions, such as in the tradition of Absurd Theatre (e.g. Hildesheimer, Beckett, Ionesco etc.), where precisely the breakdown of a communicative convention is staged in order to generate a specific dramatic intensification. However, such breaches of conventions receive their dynamics from normal communicative conventions and the expectations associated with them. Style functions in a similar way: We normally recognize stylistic breakdowns rather quickly.

In sum, text-interpretation happens in terms of the disclosure of text-genres and text-styles through the respective reading-genres and reading-styles. In every instance, cultural patterns and personal, subjective linguistic applications are related to each other - both in acts of text-composition and in acts of text-reception. Following the philosopher Manfred Frank we could say that language is always an individual universal, although I would rather speak of a personal universal. ${ }^{15}$

A second thought touches on the notion of interpretation itself. We have seen in Ricœur that every act of interpretation includes some form of understanding, however naïve it may be, which in turn ought to be accompanied by efforts of critical and self-critical explications of the text in question. However, I propose to add to

Jeanrond, Text and Interpretation, 73-128.

15 Cf. Manfred Frank, Das individuelle Allgemeine: Textstrukturierung und-interpretation nach Schleiermacher (Frankfurt am Main: Suhrkamp, 1977). 
these two dimensions a third: every act of interpretation also implies a dimension which I have called Deutung in German, assessment in English. ${ }^{16}$ The meaning of the text must be assessed. Here we are dealing with the aspect of interpretation which Schleiermacher once called divination, that means the projection or Gesamtentwurf which the interpreting subject brings about. Wishing to disclose the text's larger proposal of meaning (Sinn) implies an act of will which highlights the moral responsibility of the interpreter. In the process of interpretation we always already relate to what we understand we may reject it in total or in parts, we may consider it critically, or we may accept it.

At this junction we need to widen our horizon to include the importance of the community of speakers and interpreters in which every interpreting subject has always already been communicatively shaped and feels at home. Language is a dynamic institution which provides us with a number of genres of text-production and text-reception and which encourages us to develop our own communicative style with regard to the particular structures and hierarchies of power at work. That we can become thinking, speaking and interpreting subjects we owe to our respective communicative communities. Hence, language meets us always as a gift. Our subjectivity is never fully independent or autonomous; rather it is always already communicatively meditated. In view of this fact we must emphasise anew that human subjectivity is possible thanks to a shared language, i.e. to some measure of linguistic objectivity. Moreover, we need to stress that every communicative action changes and transforms our language, and that any communication is made possible in the first instance through the language tradition that meets us. In the beginning is and remains the Logos, i.e. the linguistic act of mediating meaning. ${ }^{17}$ Space, time and language are the categories of our being. They limit us, but at the same time they enable the transformation of our communicative community.

Theology must decide whether or not it is prepared to face this challenge. Does it wish to restrict itself to only one particular language game while tolerantly and ignorantly letting other language games

16 Jeanrond, Text and Interpretation, 64-72.

17 Cf. the first verse of the Gospel of John, 1.1: "In the beginning was the Word." 
exist outside of its own orbit? A decision in favour of one's own inward looking theological and ecclesial communicative context shuts out any struggle with the other and with otherness and thus limits the human experience of transcendence. A larger, global perspective of wrestling with the theological dimension of being human is not intended here. Rather such a narrow theological hermeneutics remains focussed on its own group-specific interpretative horizons.

The debate on the proper horizon of interpretation thus also concerns the discussion of the relationship between subjectivity and objectivity in theology and hermeneutics. Should we determine the theological horizon with regard to the specificity of a certain group or should we pursue a universal horizon? While most theological schools have been engaged with interpreting the presence of God in Scripture and world, some have concentrated more on the innerChristian dynamics and the inner-Christian pluralism, others more on the global discourse on God. The latter have been convinced that the Christian interpretation could learn from the global discourse in as much as the global discourse on a pluralistic understanding of God could benefit from a Christian horizon of interpretation.

As discussed above, some scholars favour a hermeneutics of revelation, while more globally oriented scholars prefer a hermeneutics of signification. The former claim to possess a greater theological objectivity on the basis of their subjective decision in favour of a hermeneutics of revelation. The latter claim to possess a greater theological objectivity on the basis of a decision in favour of a hermeneutics of signification. This in turn demonstrates that the choice of one's model of interpretation is never neutral. And the resulting theological discourses are only in a limited sense objective.

But there is one further difference between both approaches to hermeneutics: the defenders of a theological hermeneutics expect from their theological interpretation a deepened understanding of Christian faith in God's revelation in Jesus Christ as revealed in Holy Scripture. Hence their hermeneutics is first and foremost concerned with biblical hermeneutics. Here a preliminary fundamentaltheological decision in favour of a specific norm has been made and, as a result, the horizon of theological hermeneutics has been clearly 
defined. A struggle with the otherness of the other, i.e. with other Christians, with other interpreters of Scripture, with the otherness of God and with the otherness of one's own emerging self has already been limited to the boundaries of one's own tradition.

The representatives of a hermeneutics of signification expect from a hermeneutically conscious theology a larger struggle with the otherness of the other. Interpreting Scripture, tradition, and human experience does not happen in an isolated Christian inner-space, but in a global horizon of religious praxis. Here aspects of ideology critique enter more naturally, even with regard to original Christian dimensions of tradition which always are in need of critical and selfcritical examination. Questions concerning the structures of power in Christian communication, the construction of gender, the criteria of exclusion of all kinds of others, the recognition of different interpretative perspectives and different interpretative competences, all of these questions touch upon the assessment and appreciation of the necessary degree of subjective interpretation in any linguistically mediated witness to God's presence in our universe. Ultimately, it is the significance of human experience for the interpretation of the theological dimensions of our world which is at stake here.

The issue of 'subjectivity and objectivity' concerns both the macro-hermeneutical tasks of interpreting the world and the microhermeneutical tasks of interpreting the sacred texts of our traditions. Both hermeneutical labours are interdependent with regard to the determination of an appropriate horizon of theological thinking.

\section{The Significance of Pluralism for a Hermeneutically Conscious Theology}

All Christian churches and movements have had difficulties recognizing other and different interpretations both on the macroand micro-hermeneutical level. In the Roman Catholic Church the necessary connection between the interpretation of Scripture, tradition and human experience has always been affirmed, although the power to interpret has usually been reserved to the leadership of a hierarchically organised group of interpreters. This primacy of interpretation was generally accepted in times of very restricted general access to education. However, this acceptance has dramatically 
changed in the aftermath of humanism, renaissance, reformation and enlightenment. Larger groups of people have since gained access to the praxis of reading within and outside of the church. In addition, the new custom to read the biblical texts in the vernacular, facilitated by the emerging technique of book printing, has led to a growing interest in interpretation beyond the erstwhile groups of obvious professionals, i.e. monastic and clerical readers. Since then the conditions of communication inside and outside of the church have changed radically. At the same time, the hermeneutical horizon in both Christian traditions in the West became narrower: (a) Protestantism formally recognized that all Christians were hermeneutical subjects, but the norm determining the interpretation of religious reality was soon limited to the proper reading of Scripture according to the most recent canon of philological knowledge. (b) In Roman Catholicism it was established that authentic faith and adequate theology owe themselves to both the Bible and to Catholic tradition, although a final interpretative decision remained reserved to the hierarchically organised magisterium (teaching office) in the church.

Both Christian Churches found different answers to the Enlightenment challenges according to which every person could consider him- or herself in principle to be a proper subject within the community of interpreters. In order to establish and defend certain interpretations either one reserved access to education to specific groups of people or one appealed to the authority of the state. However, again and again new interpretative subjects have learned to articulate their own voices and introduced new hermeneutical perspectives and interpretative proposals into the ongoing discussion. Among recent theological developments in this respect I only wish to mention political theology, liberation theology, correlational theology, feminist theology, gender conscious theology, queer theology, ecological theology, postmodern theology, the emerging theology of religions etc. ${ }^{18}$ All of these new approaches in theology have been characterised by a new macro- and a new micro-hermeneutics: On the macro-hermeneutical level one refers to

18 Correlational theology aims at connecting the interpretation of scripture and tradition with an interpretation of the world in which such interpretation occurs. 
the general need to consider human experience as well as to defend the right and duty to include personal and communal experiences into the theological discourse. On the micro-hermeneutical level one refers to the vocation of all human beings to participate in the ongoing process of interpretation.

Efforts in the Roman Catholic Church to widen the community of interpreters and their respective competence have often been suppressed by the leadership of the church. This did not only affect the appeal to concrete horizons of experience in our global world, but also the vocation of so-called lay-Christians who have wished to participate in the Church's ongoing interpretation of Scripture, tradition, experience, and reason. The tension between an intransigent leadership and an increasingly self-conscious and widening community of interpreters has led to a hermeneutical pressure, even overpressure, which can no longer be sufficiently contained through the selective persecution and punishment of individual theologians. The self-understanding of modern and postmodern men and women has developed in a way that cannot be undone through efforts of hermeneutical subordination.

Rather than constantly deploring the irreconcilability between official and unofficial hermeneutical subjects and authorities, I would like to propose a different approach to finding an inner-Christian way of coping with the necessary and real pluralism of interpretations. Also with regard to the ongoing inter-religious conversation this proposal might be able to promote a more constructive approach. I shall formulate my proposal in six theses.

\section{Theology needs to choose between a hermeneutics of revelation and a hermeneutics of signification.}

As we have seen, one must make a decision whether one prefers, to quote Ricour, to take the long and difficult path through the interpretation of linguistically mediated texts and symbols to divine revelation, or to take the short cut to immediate manifestations of divine revelation. ${ }^{19}$ The short cut exists in two forms: The Protestant sola scriptura (Scripture alone) version under the slogan scriptura sui ipsius interpres (Scripture interprets itself); and the Catholic version

Ricœur, The Conflict of Interpretations, 381-401. 
as decreed for all believers by the magisterium. In both instances, Christian faith, once understood as active personal and communal discipleship, is transformed to the status of an object - now demanding assent to the respective hermeneutical pre-decisions.

\section{Even interpretations of texts aiming to steer or guide our interpretation are themselves subject to interpretation.}

Every linguistic communication represents a new hermeneutical challenge. All texts need to be interpreted and the necessary plurality of interpretations needs to be faced. Difference in an interpretation requires discussion, not repression.

\section{The hermeneutical task in theology is never completed under the conditions of space, time and language.}

Even abbreviated or interrupted processes of interpretation might represent new hermeneutical challenges. The very attempt to curtail or even to stop the pluralism of interpretations yields new hermeneutical situations. For, even normative hermeneutical decisions are hermeneutically relevant.

\section{Every interpretation of complex texts leads to a plurality of interpretations.}

We need to affirm and use our subjectivity in order to interpret complex texts. Thus, there cannot be purely objective or purely subjective interpretations as long as the interpretation is not arbitrary but genuinely concerned with the text itself. It is part of our hermeneutical condition that we human beings always understand personally. And that in turn means: We always understand somewhat differently. The point here is not to claim a total otherness, but to underline the relative otherness of our respective interpretations. We would not even be capable of expressing total otherness. But we are able to compare our respective interpretations, to examine them in a mutually constructive spirit - critically and self-critically.

\section{There is no vicarious interpretation for mature persons.}

Of course, every interpreter can take over other interpretations and appropriate them, examined or unexamined, into his or her 
own horizon. However, if the interpretation of a biblical text is to concern the Christian praxis of discipleship, then one cannot shed one's responsibility to engage in interpretation and critical and selfcritical appropriation. One can either join a certain interpretation for good reasons and shape one's discipleship accordingly, or one can search for better, more adequate interpretations in or even outside one's community of interpreters and then contribute one's hermeneutical insights to the larger inter-subjective community of interpreters. We need this public debate on adequate interpretations of texts, experiences, traditions and worldviews even in our churches in so far as they are genuinely searching for ever more adequate forms of Christian discipleship.

\section{The Christian praxis of discipleship calls for a bermeneutics of love.}

This thesis deserves a more detailed explication.

\section{Towards a Hermeneutics of Love}

In view of the rather different understanding of love in contemporary cultures it would appear to be problematic to introduce this concept into the academic discussion in general and into the hermeneutical discourse in particular. Why use a concept which has been so obviously plagued by misunderstandings?

However, in spite of all the problems associated with any attempt to understand 'love' I cannot think of another concept equally able to express the potential of dynamic and transformative networks of relationships in which women, men and children are engaged. The centre of love is the recognition of relational subjectivity. Every communal concern for adequate interpretation of texts, traditions and self-understandings must struggle with the recognition of the respective other. Such recognition is the business of love.

While empathy describes an attitude of one person toward another, love signifies a mutual, though not necessarily symmetrical relationship with other persons in which some sort of union and unity is sought without, however, the need to minimise or negate existing differences. Hence, love is not only able to preserve difference 
in a constructive way, but love lives of the very otherness of the lovers. Otherness and difference provide the fertile ground for the development of love. ${ }^{20}$

Love does not demand that we like the other. Rather the biblical love command obliges us to recognise and accept the other as other, though not necessarily to like the other. Thomas Aquinas (122574) rightly stressed that the command to love one's enemies has nothing to do with some form of harmony of feelings. We cannot force ourselves to like our enemies. But we are commanded to love them. ${ }^{21}$ Hence, love does not need to be uncritical with regard to the emotions.

Love comprises affective, cognitive, critical and self-critical dimensions of relationship. Love is more than a mere attitude (such as solidarity) or a mere feeling (such as feelings of happiness or unhappiness). Love is relation, more precisely, a network of relationships. It includes my relationships to other people, to the universe, to God as the radical other, and to my own emerging self. $^{22}$

Love, then, is not primarily concerned with a relationship that strives for harmony or even total agreement. Nor does it only seek a deeper understanding of existing differences. Hence, a hermeneutics of love does not aim either at a universalist hermeneutical access or at a relativist hermeneutical access to human communication and religious phenomena. Rather a hermeneutics of love is concerned with the dynamic encounter of persons and with their openness toward transcendence and transformation.

Such a description of a hermeneutics of love immediately connects to the old hermeneutical insight that understanding is always also engaged in the interaction between persons seeking to understand the manifestations of otherness, on the one hand, and of their horizon, their world, and their self, on the other hand. Gadamer's dictum, cited above, that being which can be understood is language, does not lose any of its validity, but needs to be

\footnotetext{
20 Cf. Werner G. Jeanrond, A Theology of Love (London/New York: T\&T Clark, 2010).

21 Ibid., 80.

22 See here esp. ibid., 19-23.
} 
complemented by the insight that all understanding always already includes a level of encounter and relationship and those human forms of relationship also always comprise a form of communicative and symbolic action. Thus the spectrum of hermeneutics is much wider than the mere interpretation of texts. Hermeneutics touches on all forms of communicative expression of which we human beings are capable. A hermeneutics of love enlarges the object of understanding beyond the written word which used to be Gadamer's favourite hermeneutical object. Gadamer never ceased to emphasise that the human relationship to the world was fundamentally linguistic and therefore comprehensible. As a result of this insight into the linguistic character and intelligibility of our relationship to the world, Gadamer asserted that hermeneutics was "a universal aspect of philosophy, and not just the methodological basis of the so-called human sciences". ${ }^{23}$ "Understanding, then, does not consist in a technical virtuosity of 'understanding' everything written. Rather, it is a genuine experience (Erfahrung) - i.e., an encounter with something that asserts itself as truth." ${ }^{24}$ However, Gadamer's hermeneutics was chiefly interested in the self-disclosure of truth and not so much in the manifestations of difference or otherness and their demands arising from such acts of disclosure.

Looking for a concept of praxis able to support both the disclosure of truth as well as the recognition of difference and otherness, I cannot find a better one than love. For, precisely in the praxis of love, that is to say in the act of opening oneself for the transformation of self and other emerging within an act of relationship, in this praxis we can see the concurrent appearance of both the disclosure of truth and the manifestation of difference. ${ }^{25}$

Already Paul Ricœur recognized this potential of love when he wrote about love in his Parcours de la Reconnaissance. ${ }^{26}$ Not as a mere emotion, but in connection with justice love supports the

\footnotetext{
23 Gadamer, Truth and Method, 476.

24 Ibid., 489.

25 See also Werner G. Jeanrond, "Theological Truth from the Perspective of an Interreligious Hermeneutics of Love", in Frederiek Depoortere and Magdalen Lambkin, eds., The Question of Theological Truth: Philosophical and Interreligious Perspectives (Amsterdam/ New York: Rodopi, 2012), 181-195.

26 Paul Ricœur, Parcours de la reconnaissance: Trois études (Paris: Stock, 2004).
} 
mutual recognition without, however, insisting on any symmetrical reciprocity. That means, in love I can accept the other, the otherness of the other, and I can relate both to the self of the other and to my own self. Ricour did not develop a hermeneutics of love. But he already saw rather clearly the significance of love for the process of relating to self and other in respect and mutual recognition.

Communities, traditions, religions, and institutions as such cannot love. Only women, men and children are able to love and in this way to participate in the construction of larger networks or bodies of love. However, at best communities, traditions, religions, and institutions transmit constructive approaches to and principles of love to the emerging subjects of love. The entry ticket into the networks of love is respect for the other and for one's own emerging self. But respect does not need to imply full agreement with the other. Every inter-human encounter contains the potential for a relationship of love, for the development of communities of understanding in which one does not only look for an intensification of the relationship, but also for an examination of the manifestation of truth and for criteria for its interpretation - both, of course, accompanied by critical and self-critical measures.

This naturally very brief outline of a hermeneutics of love must suffice here for demonstrating the significance of love for approaching the necessarily subjective and thus pluralistic tasks of theological interpretation. The different interpretations of Holy Scripture, tradition and experience can serve the community of believers as long as they recognise and take seriously other and different interpretations and invite their participation in a dialogue of love. The most important norm of theological thinking then is love - once again not in terms of liking other interpretations, but in terms of the much more difficult and often painful attempt to take part in the transformative process of a common search for truth in a conversation characterised by mutual recognition, respect, engagement and justice.

In the tradition of Christian interpretations of Scripture the central position of love has often been restated. The apostle Paul and the Church Father Augustine (354-430), for instance, saw love as the most important norm of hermeneutical activity. However, 
especially love as the God-given virtue of discipleship has also often been misused and distorted. Rather than accepting love as the God-given grace of encounter with the other and with God who is the radical other, at times love has been reduced to a mere object demanding faithful assent. Or love was lifted to the level of a criterion of exclusion: so in the slogan that only Christians possess proper love. Thus, even theologies of love might need to be exposed as powerful examples of the complex effort to construct religious identity at the expense of others.

Since the sixteenth century one often speaks of "Christian love" and no longer of a Christian praxis of love alongside, for instance, a Muslim and a Jewish praxis of love. Søren Kierkegaard (1813-55), Anders Nygren (1890-1978), Karl Barth and Eberhard Jüngel (b. 1934), to name just a few thinkers, all have redefined love in terms of a specific Christian virtue. Here we encounter a Christianity which in my mind is wrong in claiming to be the only genuine religion of love, while other religions are more or less brutally disowned in this respect. Such a monopolising understanding of love is all the more surprising in view of the fact that the synoptic gospels portray Jesus as quoting directly from the Torah when he explains the dual love command and thus confirms that the entire Scriptures celebrate God's gift of love.

These examples may illustrate how much religious traditions have understood themselves in opposition to all those others and how much they have attempted to ground their own identities on the exclusion of those others. Too often those others have been excluded from the process of searching for forms of authentic communication of truth and have been deprived from the horizon of love. A priori exclusion of others from the process of interpreting Scripture, tradition and experience amounts to a perversion of love into its opposite, namely indifference for or rejection of these others. Here the other is no longer of interest for the very effort to find truth. But we should ask: can one seriously search for God, who is the radical other, pray to God and love God while at the same time ignoring God's creative and transformative presence in the human other? 


\section{Conclusion}

In this article I have attempted to present some outlines for a hermeneutics of love which would allow us to take seriously both subjectivity and objectivity in the process of interpretation and which would encourage us no longer to consider the necessary pluralism of interpretation as a threat to faith, truth and religious community. If love were considered to provide the most important norm in our search for truth, then religious people could approach their tasks of interpreting their sacred Scriptures, their traditions and the different manifestations of divine presence, and their own critical and self-critical understanding of human experience in the different and shifting contexts of their lives with great joy and renewed enthusiasm.

Of course, even the praxis of love needs to be examined critically and self-critically. Love is not a Christian possession. Rather Christians like Muslims, Jews and other religious people have always again reflected upon the challenge of how best to face otherness and the transformation which could be ignited through loving acts of recognition. Hence, love needs to be understood as a praxis to which all human beings are called. The transcending power of love is always revolutionary. How could a hermeneutics of love be otherwise? 